EXPERIMENTAL STUDY

\title{
Differences between the effects of thyroxine and tetraiodothyroacetic acid on TSH suppression and cardiac hypertrophy
}

\author{
Nathalie Lameloise, Catherine Siegrist-Kaiser, Maureen O'Connell ${ }^{1}$ and Albert Burger \\ Thyroid Unit, Division of Endocrinology and Metabolism, Department of Medicine, University of Geneva, Switzerland and ${ }^{1}$ Biometry Unit, \\ University of Vermont, Burlington, Vermont, USA \\ (Correspondence should be addressed to A Burger, Thyroid Unit, Hôpital Cantonal Universitaire, CH 1211 Geneva 14, Switzerland; \\ Email: burger@cmu.unige.ch)
}

\begin{abstract}
Objective: We earlier reported marked qualitative differences between the effect of 3,5,3'-triiodothyroacetic acid (Triac) and tri-iodothyronine $\left(\mathrm{T}_{3}\right)$ on cardiac hypertrophy at equivalent thyroidstimulating hormone (TSH)-suppressive doses. We have now extended these studies to specific cardiac parameters. Due to its rapid metabolic clearance rate, Triac is not suitable for TSH suppression and therefore the slowly metabolized 3,5,3',5'-tetraiodothyroacetic acid (Tetrac), the precursor of Triac, was studied.

Methods: Hypothyroid rats were infused over 13 days with 1.5-40.5 nmol Tetrac/day per $100 \mathrm{~g}$ body weight (BW) or with $0.5-13.5 \mathrm{nmol}$ thyroxine $\left(\mathrm{T}_{4}\right) /$ day per $100 \mathrm{~g} \mathrm{BW}$.

Results: The responses of serum TSH and of hepatic monodeiodinase type 1 were parallel for both hormones, their potency ratios could therefore be compared. Tetrac was revealed as being only half as active on hepatic monoiodinase type 1 despite a similar serum TSH levels. Tetrac can therefore be considered to have a preferential action on serum TSH suppression. The cardiac effects on $\mathrm{Ca}^{2+}$ ATPase (SERCA 2a) and monodeiodinase type 1 activity were qualitatively different and therefore one cannot give an overall quantitative estimate of these differences. The results showed clearly, however, that Tetrac is less efficient for all parameters studied, namely induction of cardiac hypertrophy, $\alpha-$ myosin heavy chain mRNA, monodeiodinase type 1 activity and mRNA levels of the sarcoplasmic SERCA 2a.

Conclusion: We postulate therefore that, in the rat and possibly in man, Tetrac could represent a favorable alternative for suppression of serum TSH levels.
\end{abstract}

European Journal of Endocrinology 144 145-154

\section{Introduction}

In the mid 1950s 3,5,3',5'-tetraiodothyroacetic acid (Tetrac) was studied as a potential substitute for thyroxine $\left(\mathrm{T}_{4}\right)$ for treating myxedema and for its effects on peripheral lipid metabolism in humans (1-3). Except for the higher doses of Tetrac required, no clear differences in the clinical or lipid outcomes were found between Tetrac and $\mathrm{T}_{4}$. More recent human studies of the ability of 3,5,3'-tri-iodothyroacetic acid (Triac), the active metabolite of Tetrac, to suppress thyroid-stimulating hormone (TSH) uncovered higher thyromimetic effects of Triac relative to $\mathrm{T}_{4}$ on liver metabolism (4-7).

In the rat, studies with Triac revealed differences with tri-iodothyronine $\left(\mathrm{T}_{3}\right)$ for cardiac hypertrophy and cardiac monodeiodinase type 1 activity $(8,9)$. These differential peripheral sensitivities and actions of Triac might be used for clinical benefit. The problem of its short half-life can be overcome by administering Tetrac, its slowly metabolized precursor, and Tetrac might even have an additional advantage over Triac and $\mathrm{T}_{4}$ since it might allow excellent inhibition of serum TSH without inducing subclinical hyperthyroidism. This is because the intrapituitary conversion of $\mathrm{T}_{4}$ to $\mathrm{T}_{3}$ that is required for TSH suppression is reduced by the simultaneous inhibition of the monodeiodinase type 2 as physiologic levels of $\mathrm{T}_{4}$ are achieved, decreasing the intrapituitary production of $\mathrm{T}_{3}$. Therefore, larger than metabolically required replacement doses of $\mathrm{T}_{4}$ are required to suppress TSH below normal levels. Such states of subclinical hyperthyroidism are the therapeutic goal for many patients with thyroid malignancies. Tetrac, on the other hand, because it does not inhibit, in vitro, monodeiodinase type 2 , could possibly suppress TSH at less than its equivalent $\mathrm{T}_{4}$ peripheral thyromimetic dose 
by allowing the continued production of Triac with its similar potency to $\mathrm{T}_{3}$ for suppressing TSH (10). The present studies assess the effects of Tetrac and $\mathrm{T}_{4}$ on heart and pituitary at equivalent TSH-suppressing concentrations on gene regulation and enzyme activities in vivo in rats.

\section{Materials and methods}

\section{Materials}

Thyroid hormones $\left(3,3^{\prime}\right.$-di-iodothyronine $\left.\left(\mathrm{T}_{2}\right), \mathrm{T}_{3}, \mathrm{~T}_{4}\right)$ and their analogs Diac, Triac and Tetrac were obtained from Henning Co. (Berlin, Germany). All the chemical reagents used were purchased from Fluka (Buchs, Switzerland), Sigma Chemical Co. (St Louis, MO, USA) or Merck (Darmstadt, Germany). Osmotic mini-pumps (model 2002) were purchased from Alzet (Palo Alto, CA, USA).

Carrier-free $\left[{ }^{125} \mathrm{I}\right] \mathrm{Na}$ was purchased from Amersham International plc (Amersham, Bucks, UK) and $\left[{ }^{131} \mathrm{I}\right] \mathrm{Na}$ from Nuklear Reaktor (Würenlingen, Switzerland). $\mathrm{T}_{3}$, $\mathrm{T}_{4}$, Triac and Tetrac were labeled with ${ }^{125} \mathrm{I}$ by the chloramine-T method using 3,5- $\mathrm{T}_{2}, \mathrm{~L}-\mathrm{T}_{3}$, Diac and Triac as substrate respectively (11). Specific activities thus achieved were higher than $1200 \mu \mathrm{Ci} / \mu \mathrm{g}$.

\section{Experimental protocol}

Seventy-nine male SIVZ rats were purchased from the breeder (Institut für Labortierkunde des Universität Zürich, Zürich, Switzerland). They were rendered hypothyroid by a single injection of $\left[{ }^{131} \mathrm{I}\right] \mathrm{Na}$ $(100 \mu \mathrm{Ci} / \mathrm{rat})$ and before and throughout the experiment $0.02 \%$ 2-mercapto-1-methylimidazol (MMI) was added to drinking water. In order to have a euthyroid control group of similar weight and identical age, ten rats received only MMI in the drinking water and, 2 weeks before implanting the minipumps, MMI was withdrawn. Osmotic minipumps (secretion rate $0.25 \mu \mathrm{l} / \mathrm{h}$, duration 14 days) were implanted i.p. 2 months after the injection of $\left.{ }^{131} \mathrm{I}\right] \mathrm{Na}$. The minipumps were filled with $\mathrm{T}_{4}$ or Tetrac dissolved in $0.05 \mathrm{M} \mathrm{NaOH}$, $2 \%$ bovine serum albumin and 100000 c.p.m. $\left[{ }^{125} \mathrm{I}\right] \mathrm{T}_{4}$ or $\left[{ }^{125} \mathrm{I}\right]$ Tetrac as a control of their secretion rates. The infusion lasted 13 days. Doses of $0,1.5,4.5,13.5$ and $40.5 \mathrm{nmol}$ Tetrac/day per $100 \mathrm{~g}$ body weight (BW) or $0.5,1.5,4.5$ and $13.5 \mathrm{nmol} \mathrm{T}_{4}$ /day per $100 \mathrm{~g} \mathrm{BW}(n=$ $4 /$ dose) were infused. A euthyroid control group was included. The animals were weighed every 2 days. Rats were killed by decapitation and blood was collected and stored at $-20{ }^{\circ} \mathrm{C}$ until use. Tissues (liver, heart, brown adipose tissue (BAT), cerebral cortex and pituitary) were removed rapidly, frozen in liquid nitrogen and stored at $-70{ }^{\circ} \mathrm{C}$ until use.

\section{Hormone assays}

Total serum $\mathrm{T}_{4}, \mathrm{~T}_{3}$, Tetrac, Triac and TSH levels (intraassay coefficient of variation $7-10 \%$, interassay coefficient of variation $12-15 \%)$ were measured using in-house methods. Serum TSH measurements were performed with reagents kindly provided by the National Pituitary Program, NIAMDD, NIH (Bethesda, $\mathrm{MD}$, USA). The detection limits were $0.80 \mathrm{ng} \mathrm{TSH} / \mathrm{ml}$, $9.5 \mathrm{pmol} \mathrm{T} / \mathrm{ml}, 0.16 \mathrm{pmol} \mathrm{T} / 3 / \mathrm{ml}, 10 \mathrm{pmol} \mathrm{Tetrac} / \mathrm{ml}$ and $0.52 \mathrm{pmol}$ Triac $/ \mathrm{ml}$.

\section{Monodeiodinase type 1 and 2 activities}

Monodeiodinase type 1 and type 2 activities were determined in tissue homogenates by measuring the release of radioiodide from $\left[{ }^{125} \mathrm{I}\right]$ reverse $\mathrm{T}_{3}\left(\mathrm{rT}_{3}\right)$ according to the method of Leonard \& Rosenberg (12).

Monodeiodinase type 1 activity was measured in liver homogenates using $1 \mu \mathrm{M} \mathrm{rT} \mathrm{r}_{3}$ and $1 \mathrm{mM}$ DTT with $10 \mathrm{~min}$ of incubation, whereas for heart tissue, $0.01 \mu \mathrm{M} \mathrm{rT}_{3}$ and $10 \mathrm{mM}$ DTT with $1 \mathrm{~h}$ of incubation were used. Monodeiodinase type 2 activity was measured in BAT and cerebral cortex using $1 \mathrm{nM} \mathrm{rT}_{3}$, $10 \mathrm{mM}$ DTT and $1 \mathrm{mM}$ propylthiouracil with $1 \mathrm{~h}$ of incubation. Protein concentrations were measured by the method of Bradford (Bio-Rad Laboratories $\mathrm{GmbH}$, Munich, Germany) with bovine gammaglobulin as the protein standard.

In order to study the effect of circulating Tetrac on the measurement of enzyme activities, two rats were injected i.p. with $10 \mu \mathrm{Ci}\left[{ }^{125} \mathrm{I}\right] \mathrm{Tetrac}$ and killed $6 \mathrm{~h}$ later. The tissue homogenates were extracted with 3 vol ethanol- $\mathrm{NH}_{3}(97: 3)$. After 10 min centrifugation at $15000 \boldsymbol{g}$, the supernatant was vacuum dried and applied on thin-layer chromatograms (Merck 254; toluol, acetic acid, water: $2: 2: 1$ ). In order to calculate the tissue concentrations, the highest serum Tetrac levels were used $(406 \mathrm{pmol} / \mathrm{ml})$. The calculated tissue concentrations were: liver 1.9, heart 2.29 and brain cortex $0.47 \mathrm{fmol} \mathrm{Tetrac} / \mu \mathrm{g}$ protein.

\section{Total RNA extraction and Northern blot hybridization}

Total RNA was extracted by the method of Chomczynski \& Sacchi (13). The probe for monodeiodinase type 1 was kindly provided by $\operatorname{Dr}$ P R Larsen (Harvard Medical School, Boston, MA, USA), for monodeiodinase type 2 by Dr D L St Germain (Lebanon, NH, USA), the rat growth hormone (rGH) probe by Dr F DeNoto (University of California, San Francisco, CA, USA) and the probe for rat cardiac reticulum sarcoplasmic $\mathrm{Ca}^{2+}$ ATPase (SERCA 2a) by Dr W H Dillmann and Dr R Sayen (Medical Center of University of California, San Diego, CA, USA). The probes for $\alpha$ - and $\beta$-myosin heavy chain $(\alpha-\mathrm{MHC}$ and $\beta$-MHC) were synthesized by Microsynth GmbH (Balgach, Switzerland). Probes were 
labeled by $\gamma\left[{ }^{32} \mathrm{P}\right] \mathrm{dCTP}$ using a random oligonucleotide priming kit $\left({ }^{\mathrm{T} 7}\right.$ QuickPrime ${ }^{\mathrm{TM}}$ Kit; Pharmacia Biotech, Uppsala, Sweden) to a specific activity of $1 \times$ $10^{9}$ c.p.m. $/ \mu$ g DNA except for $\alpha$ - and $\beta-\mathrm{MHC}$ using polynucleotide kinase T4 with $\gamma\left[{ }^{32} \mathrm{P}\right] \mathrm{dATP}$. Hybridization was carried out at $42{ }^{\circ} \mathrm{C}$.

The amount of labeled mRNA was quantified by scanning laser densitometry (Phosphorimager; Molecular Dynamics, Sunnyvale, CA, USA). Variations in RNA loading and transfer were corrected by densitometric quantification of a negative photograph of $28 \mathrm{~S}$ and $18 \mathrm{~S}$ ribosomal RNA bands from ethidium bromide-stained RNA gels.

The final values were obtained by using the groups treated with 0.5 and $1.5 \mathrm{nmol} \mathrm{T}_{4}$ /day per $100 \mathrm{~g} \mathrm{BW}$ (depending on the tissue) as control and expressed in arbitrary units. Each membrane contained a 0.5 and/ or a $1.5 \mathrm{nmol} \mathrm{T}_{4} /$ day per $100 \mathrm{~g} \mathrm{BW}$ sample. For the RNA levels of pituitary monodeiodinase type 2 the densitometric value of the highest dose of $\mathrm{T}_{4}$ was used as internal standard.

\section{Statistical methods}

A two-way analysis of variance (ANOVA) was used to estimate differences among the two treatment groups, over the increasing doses of the hormones (four levels), and the interaction between treatment and dose levels (SAS General Linear Models program) (14). The dose levels at a 1:3 molar ratio were considered for $1,3,9$ and 27 times the lowest dose. A one-way analysis of covariance, with $\ln$ (TSH) as the covariate, was performed using BMDP software (IV), which also includes a test for parallel regression slopes (15). When the two treatment groups shared a common slope, adjusted mean values for each treatment group were calculated at the overall mean $\ln (\mathrm{TSH})$ concentration. Most variables were log transformed to improve linearity for these analyses. Significance was considered at $P<0.05$.

\section{Results}

As may be seen in Table 1, animals treated with Tetrac and $\mathrm{T}_{4}$ gained weight during the 13 days of treatment. With the highest doses of Tetrac and $\mathrm{T}_{4}$ the final weight gain was inferior to the other groups. This can be explained by their hyperthyroid status induced by both hormones.

For both treatments, the increase in liver weight was parallel to the increase in BW (data not shown). However, the heart weight increased faster than BW with increasing infusion rates of $\mathrm{T}_{4}$. In contrast to $\mathrm{T}_{4}$, Tetrac induced a much milder cardiac hypertrophy $(P<0.01)$.

Due to the strong binding to prealbumin, serum Tetrac levels were high but serum Triac levels remain low. The ratio of serum Triac to Tetrac was lower than the $\mathrm{T}_{3}$ to $\mathrm{T}_{4}$ ratio (Table 2). Despite these high serum Tetrac levels, the contamination of the homogenates with Tetrac was not sufficient to affect the enzyme assay. In brain cortex homogenates, the concentration was less than $1 \mathrm{fmol} / \mu \mathrm{g}$ protein. The addition of Tetrac to a monodeiodinase type 2 assay using microsomol protein from brain cortex showed, with 1 fmol Tetrac/ $\mu \mathrm{g}$ protein, $90.5 \%$ of the full activity. Similar results were obtained by the addition of $\mathrm{T}_{4}$ or $\mathrm{rT}_{3}$.

Based on preliminary studies, which indicated a relative TSH-suppressive potency of $1-3$, infusions at a molar $\mathrm{T}_{4}$ to Tetrac ratio of 1:3 were chosen. For this reason, in the ANOVA calculations, the molar ratios were used. In Fig. 1 the effects of the two hormones on the two cardiac parameters, monodeiodinase type 1 activity and SERCA 2a mRNA levels, are shown. Inspection of Fig. 1 demonstrates the weak response to increasing doses of Tetrac compared with $\mathrm{T}_{4}(P<$ 0.001). In the ANOVA, a significant interaction between the two hormone treatments $(P=0.003$ for heart monodeiodinase type $1, P=<0.001$ for SERCA $2 \mathrm{a})$ verifies this difference in response. This represents one of the two major findings of this study. For $\alpha$ - and $\beta$-MHC there was, however, no interaction with dose and treatment (Fig. 2).

Table 1 Whole body and heart weights. Values are means \pm S.E.M.

\begin{tabular}{|c|c|c|c|c|c|c|}
\hline & \multirow{2}{*}{$\begin{array}{c}\text { Infusion } \\
\text { (nmol/100 g BW per day) }\end{array}$} & \multirow[b]{2}{*}{ Molar ratio } & \multicolumn{2}{|c|}{ Body weight (g) } & \multirow[b]{2}{*}{ Heart (g) } & \multirow[b]{2}{*}{ Heart/BW (\%) } \\
\hline & & & At day 0 & Increase after 13 days & & \\
\hline \multirow[t]{4}{*}{ Tetrac infusion } & 1.5 & 1 & $229.9 \pm 6.3$ & $14.0 \pm 1.8$ & $0.76 \pm 0.02$ & $0.31 \pm 0.01$ \\
\hline & 4.5 & 3 & $228.2 \pm 7.0$ & $27.1 \pm 1.3$ & $0.83 \pm 0.04$ & $0.33 \pm 0.02$ \\
\hline & 13.5 & 9 & $230.0 \pm 4.3$ & $33.9 \pm 2.2$ & $0.94 \pm 0.03$ & $0.36 \pm 0.01$ \\
\hline & 40.5 & 27 & $235.0 \pm 14.9$ & $15.5 \pm 4.8$ & $0.98 \pm 0.06$ & $0.39 \pm 0.02^{a}$ \\
\hline \multirow[t]{4}{*}{$\mathrm{T}_{4}$ infusion } & 0.5 & 1 & $230.0 \pm 14.3$ & $18.5 \pm 2.1$ & $0.86 \pm 0.06$ & $0.35 \pm 0.02$ \\
\hline & 1.5 & 3 & $231.2 \pm 5.3$ & $31.1 \pm 3.0$ & $0.90 \pm 0.04$ & $0.34 \pm 0.01$ \\
\hline & 4.5 & 9 & $230.8 \pm 8.9$ & $32.1 \pm 2.3$ & $1.19 \pm 0.03$ & $0.45 \pm 0.02$ \\
\hline & 13.5 & 27 & $230.0 \pm 10.1$ & $14.8 \pm 6.4$ & $1.32 \pm 0.11$ & $0.54 \pm 0.02$ \\
\hline Euthyroid & & & $233.4 \pm 9.4$ & $60.8 \pm 5.4$ & $1.04 \pm 0.05$ & $0.38 \pm 0.01$ \\
\hline Hypothyroid & & & $226.4 \pm 8.9$ & $1.3 \pm 1.9$ & $0.61 \pm 0.03$ & $0.27 \pm 0.01$ \\
\hline
\end{tabular}


Table 2 Serum values of TSH, $\mathrm{T}_{4}, \mathrm{~T}_{3}$, Triac and Tetrac. Values are means \pm S.E.M.

\begin{tabular}{|c|c|c|c|c|c|c|c|}
\hline & \multirow[b]{2}{*}{ Molar ratio } & \multirow{2}{*}{$\begin{array}{c}\text { Infusion } \\
\text { (nmol/100 g BW per day) }\end{array}$} & \multicolumn{5}{|c|}{ Serum values } \\
\hline & & & TSH (ng/ml) & $\mathrm{T}_{3}(\mathrm{pmol} / \mathrm{ml})$ & $\mathrm{T}_{4}(\mathrm{pmol} / \mathrm{ml})$ & Triac $(\mathrm{pmol} / \mathrm{ml})$ & Tetrac $(\mathrm{pmol} / \mathrm{ml})$ \\
\hline \multirow[t]{4}{*}{ Tetrac infusion } & 1 & 1.5 & $90.3 \pm 8 \cdot 6$ & & & $1.1 \pm 0.3$ & $168 \pm 16$ \\
\hline & 3 & 4.5 & $4.6 \pm 0.5$ & & & $1.1 \pm 0.2$ & $332 \pm 19$ \\
\hline & 9 & 13.5 & $1.2 \pm 0.3$ & & & $2.4 \pm 0.5$ & $458 \pm 27$ \\
\hline & 27 & 40.5 & $<0.8$ & & & $6.3 \pm 1.7$ & $406 \pm 57$ \\
\hline \multirow[t]{4}{*}{$\mathrm{T}_{4}$ infusion } & 1 & 0.5 & $110.2 \pm 10.8$ & $0.7 \pm 0.0$ & $43.1 \pm 2.8$ & & \\
\hline & 3 & 1.5 & $11.8 \pm 3.0$ & $1.2 \pm 0.1$ & $77.1 \pm 9.4$ & & \\
\hline & 9 & 4.5 & $1.0 \pm 0.2$ & $3.4 \pm 0.2$ & $129.7 \pm 9.5$ & & \\
\hline & 27 & 13.5 & $<0.8$ & $24.0 \pm 0.7$ & $353.4 \pm 31.7$ & & \\
\hline Euthyroid & & & $7.9 \pm 1.1$ & $2.1 \pm 0.2$ & $81.9 \pm 6.1$ & & \\
\hline Hypothyroid & & & $76.7 \pm 6.4$ & $0.2 \pm 0.0$ & & & \\
\hline
\end{tabular}

Serum TSH values were significantly lower in the Tetrac-treated rats when compared with the $T_{4}$-treated rats with the same molar ratio infusion rate $(P<0.05)$.
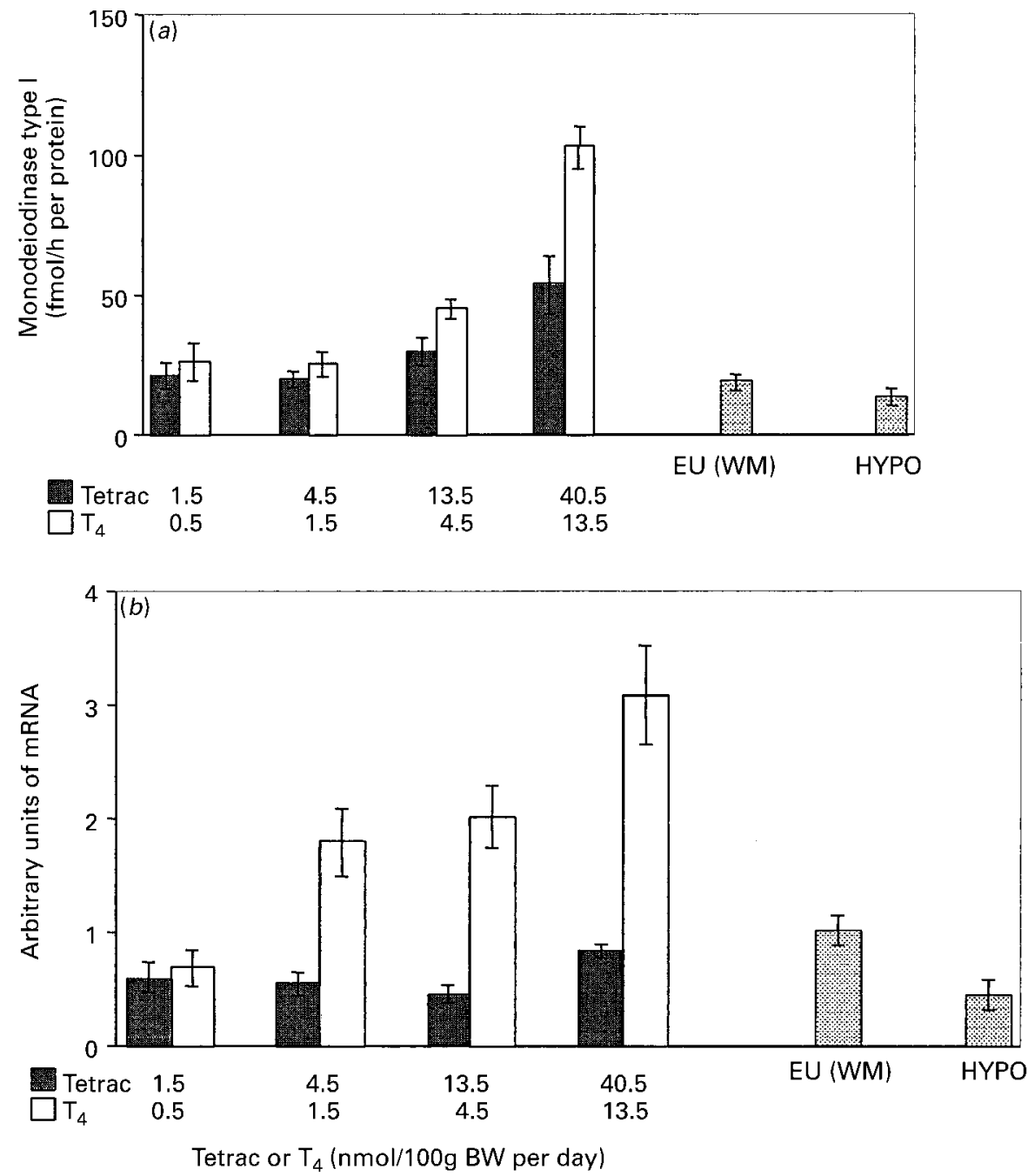

Figure 1 Effect of Tetrac and $\mathrm{T}_{4}$ treatments on the (a) cardiac monodeiodinase type 1 activity and $(b)$ mRNA levels of SERCA 2a. For both parameters, the incremental increase in response to Tetrac is much weaker than for $\mathrm{T}_{4}(P<0.001)$, and response differences between the treated groups are not consistent over the increasing dose levels (interaction between dose and treatment, $P<0.005$ for both parameters). For the definition of the densitometric quantification, see Materials and methods. EU (WM), euthyroid; Hypo, hypothyroid. Values are means \pm S.E.M. 

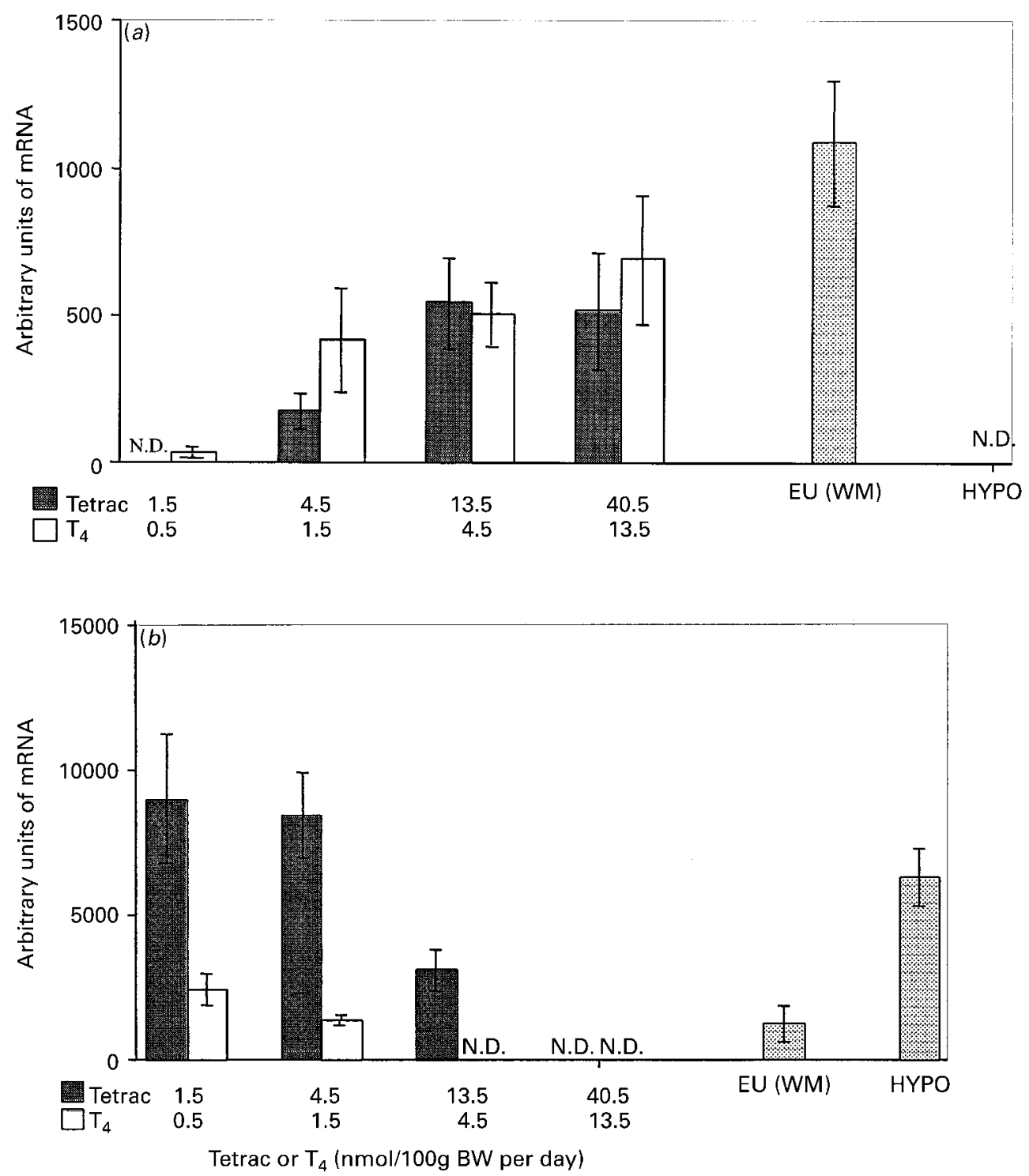

Figure 2 (a) $\alpha$-MHC mRNA values were not significantly different between the two treatments groups. (b) $\beta$-MHC values were significantly different between the treatment groups $(P<0.001)$ and this difference was consistent over the three dose levels considered. In $(a)$ the lowest dose and in $(b)$ the highest dose were not included in the statistical calculations. EU (WM), euthyroid; Hypo, hypothyroid; N.D., not determined. Values are means \pm S.E.M.

In contrast to the cardiac effects, the hepatic response (monodeiodinase type 1 activity and mRNA levels) to increasing doses of the two hormones was parallel and in addition, $\mathrm{T}_{4}$ was more potent at all dose levels $(P=$ 0.001 and for liver mRNA $P=0.053$ ) (Fig. 3).

There was no treatment difference for the response of rGH mRNA (Fig. 4a). In Figs $4 b$ and 5 the response of monodeiodinase type 2 is illustrated. The inhibition of the pituitary mRNA levels of monodeiodinase type 2 was less efficient with Tetrac than with $\mathrm{T}_{4}(P=0.001)$ (Fig. $4 b$ ). The monodeiodinase type 2 activity of brain cortex was also less affected by Tetrac than by $\mathrm{T}_{4}$ $(P=0.001)$ (Fig. 5a) and in BAT the difference was present $(P<0.001)$ but less striking (Fig. 5b).
Since serum TSH concentrations were found to be higher in the $\mathrm{T}_{4}$-treated rats compared with the Tetractreated rats (mean of $31 \mathrm{vs} 24 \mathrm{ng} / \mathrm{ml}, P=<0.04$ ), the data were reanalyzed using an analysis of covariance with the natural log of TSH $(\ln (\mathrm{TSH}))$ as the covariate. For those variables where the two treatment groups had a similar response slope compared with their ln (TSH) concentrations, adjusted group means could be calculated at the overall group $\ln (\mathrm{TSH})$ concentration. Fig. 6 demonstrates the plot of $\ln (\mathrm{TSH})$ against $\ln$ (hepatic monodeiodinase type 1 activity). It was therefore possible to predict, at a mean serum TSH concentration, the mean effect of $\mathrm{T}_{4}$ or Tetrac on the parameters studied as an indication of the relative 

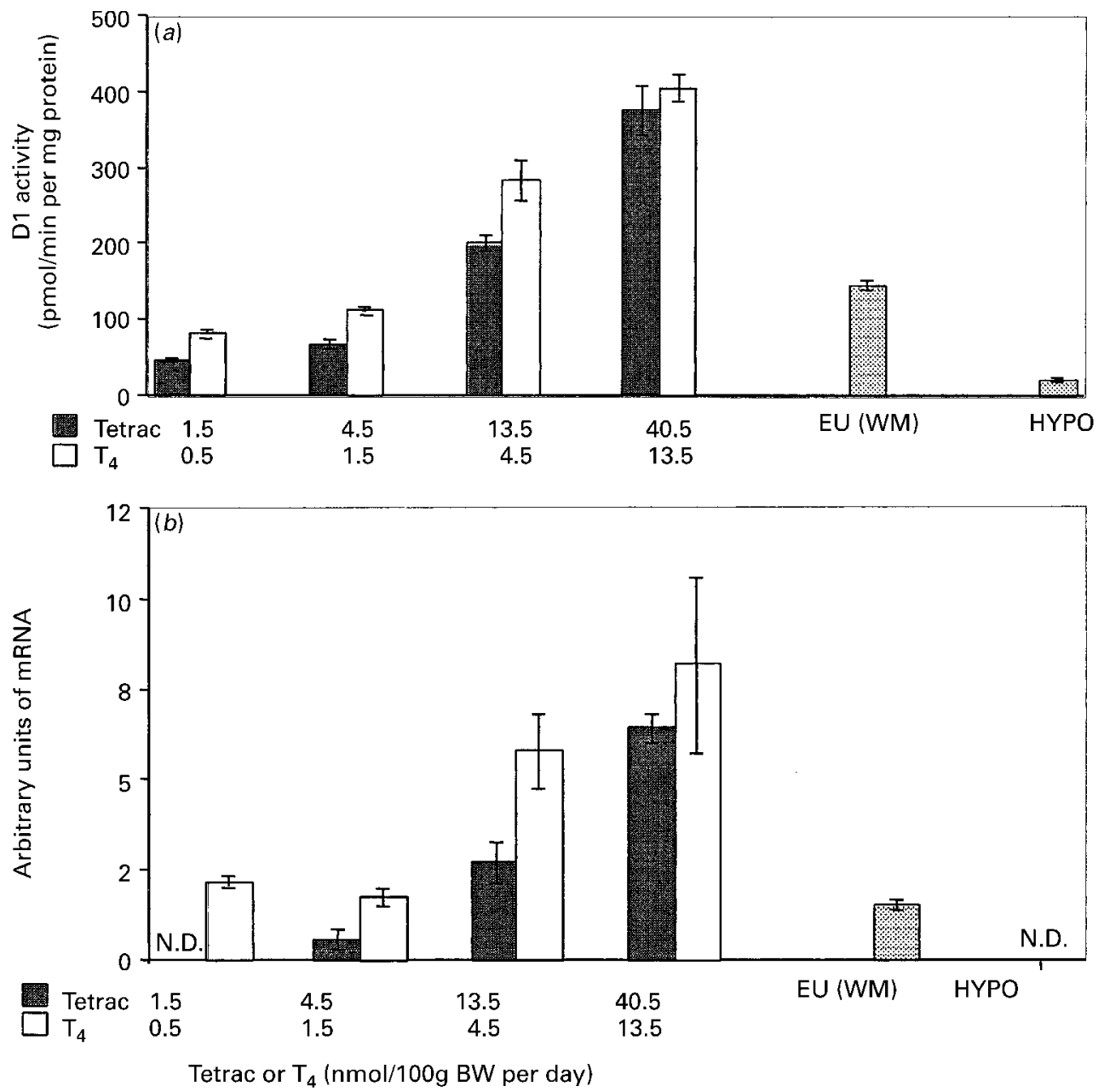

Figure 3 Effect of Tetrac and $T_{4}$ treatments on (a) the hepatic monodeiodinase type 1 (D1) activity and (b) its mRNA levels. In both cases, the increase in response is consistent across all dose levels. EU (WM), euthyroid; Hypo, hypothyroid; N.D., not determined. Values are means \pm S.E.M.

activities of these two hormones on these parameters. The results are summarized in Table 3. They indicate that at an equal serum TSH concentration, hepatic monodeiodinase type 1 activity and mRNA levels were less stimulated in Tetrac-treated rats ( 59 and $49 \%$ of the value in $\mathrm{T}_{4}$-treated rats). This means that for this parameter we had overestimated the potency of Tetrac by using a 1:3 molar infusion ratio for comparison. Tetrac was also less active than $\mathrm{T}_{4}$ in reducing the excessive monodeiodinase type 2 activity characteristic for hypothyroid cortex. In Table 3 the results are expressed in terms of remaining activity and, therefore, the activity of the enzyme was higher with the poorer inhibitor.

\section{Discussion}

Similar to $\mathrm{T}_{4}$, Tetrac is a good substrate for monodeiodinase type 1 and is converted to Triac (16). According to the in vitro affinities to $\mathrm{T}_{3}$ receptors it is also suggested that Tetrac acts as a prohormone and that Triac is the active compound with a high affinity for $\mathrm{T}_{3}$ receptors $(17-19)$. It may be puzzling to find a smaller Triac to Tetrac serum ratio compared with the $\mathrm{T}_{3}$ to $\mathrm{T}_{4}$ ratio. We have published the metabolic clearance rate of Triac which, in the rat, does not differ from $\mathrm{T}_{3}(28 \mathrm{ml} / \mathrm{h}$ per $100 \mathrm{~g} \mathrm{BW})(9)$. Using the present serum Triac levels, the above-mentioned MCR and the infusion rates of Tetrac, one can estimate the conversion rate. It is approximately $30 \%$ and therefore similar to the one of $\mathrm{T}_{4}$ to $\mathrm{T}_{3}$. We assume that the explanation for the difference in serum ratio is the consequence of a very high affinity of transthyretin for Tetrac (11).

Few direct effects of $\mathrm{T}_{4}$ have been well documented, the marked inhibition of monodeiodinase type 2 activity being the best example $(20,21)$. The physiological relevance of this effect has been clearly established and probably plays a crucial role for an increased intrapituitary conversion of $\mathrm{T}_{4}$ to $\mathrm{T}_{3}$ in the hypothyroid state while normal serum $\mathrm{T}_{4}$ concentrations 

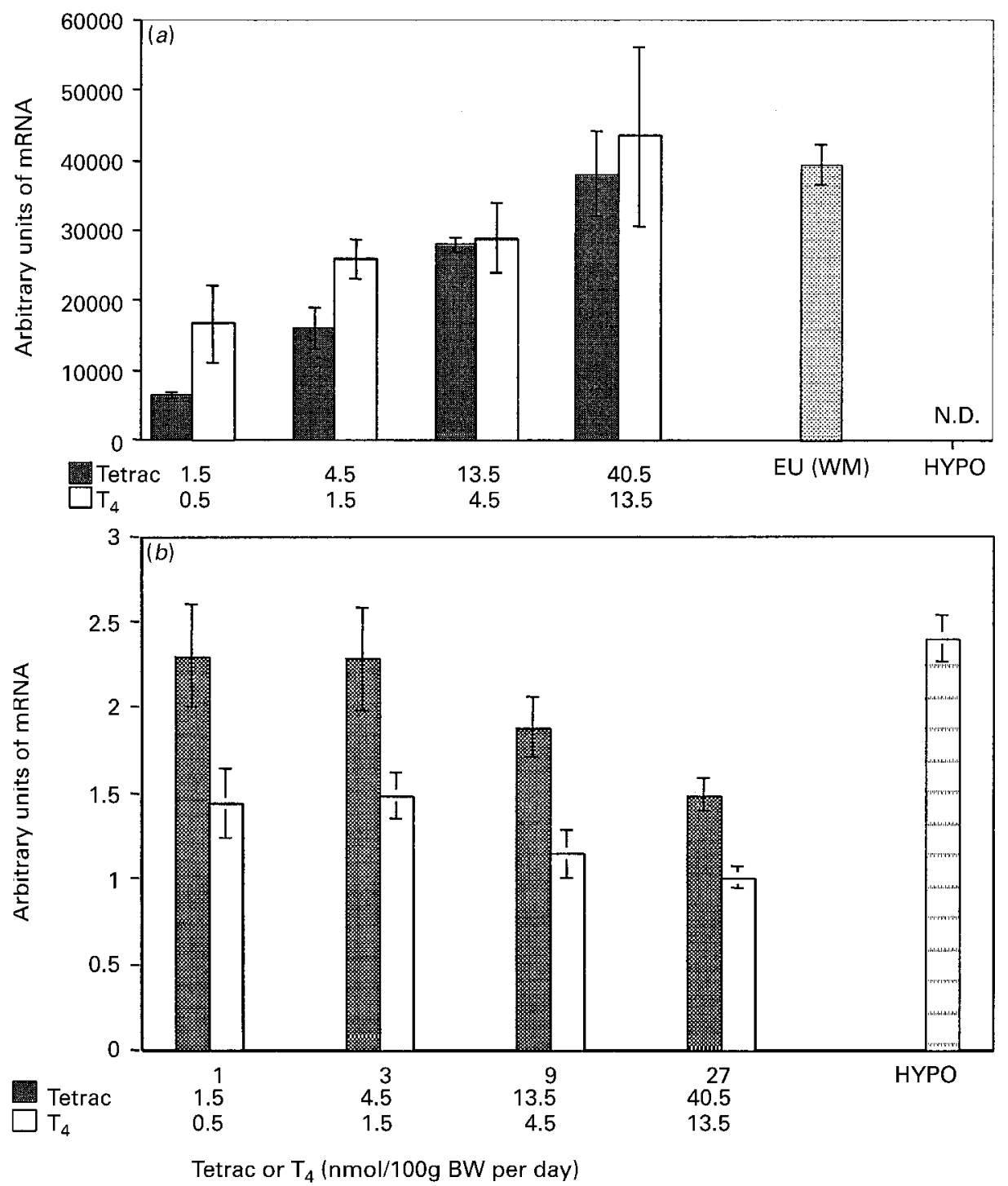

Figure 4 Effect of Tetrac and $\mathrm{T}_{4}$ treatments on the expression of (a) $\mathrm{rGH}$ mRNA in the pituitary. There was no significant difference between treatments over the dose levels considered $(P=0.14)$. (b) Tetrac treatment was significantly weaker in suppressing pituitary mondeiodinase type $2 \mathrm{mRNA}$ levels of the pituitary, $P=0.001$. EU (WM), euthyroid; Hypo, hypothyroid; N.D., not determined. Values are means \pm S.E.M.

inhibit the enzyme activity and, thus, the intrapituitary conversion of $\mathrm{T}_{4}$ to $\mathrm{T}_{3}$ is decreased $(22,23)$. Tetrac differs from $\mathrm{T}_{4}$ since it has been shown that a large excess of Tetrac is not able to inhibit monodeiodinase type 2 activity in glial cell cultures. In our present experiments the in vitro results were not fully reproduced. In terms of activity, this is clearly seen by some inhibition of monodeiodinase type 2 activity of brain cortex with high Tetrac concentrations (Fig. 5a). There was insufficient pituitary material for measurements of enzyme activity and RNA extraction. It is, however, known that monodeiodinase type 2 activities of cerebral cortex and pituitary correlate well (24). In addition, the results of the Northern blot of pituitary monodeiodinase type 2 mRNA show a difference between the effect of $\mathrm{T}_{4}$ and Tetrac which suggests that a long-term non-nuclear effect such as the inhibition of mondeiodinase type 2 activity will affect mRNA expression.

We are therefore able to conclude that in hypothyroid and euthyroid conditions, Tetrac is clearly a weaker inhibitor of monodeiodinase type 2 activity than $\mathrm{T}_{4}$. If this difference could also be found in humans, it would be of major clinical importance since it follows that for a similar peripheral effect of $\mathrm{T}_{4}$ and Tetrac one can expect a more pronounced inhibition of TSH secretion.

Concerning the nuclear effects and assuming that they are mediated by Triac, one might assume that 

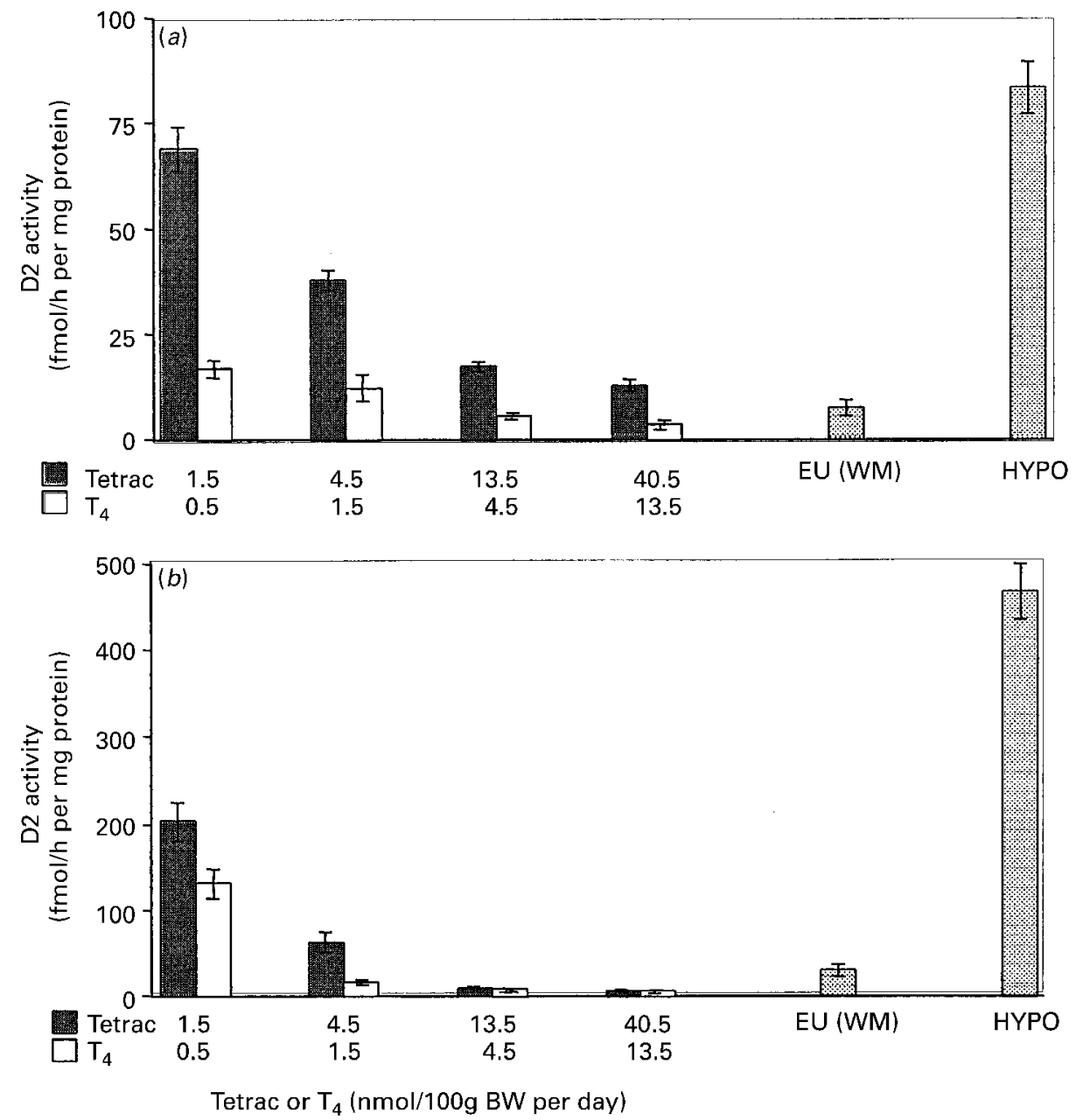

Figure 5 Effect of Tetrac and $T_{4}$ treatments on the monodeiodinase type 2 (D2) activity of (a) cerebral cortex and (b) BAT. In these tissues, $\mathrm{T}_{4}$ treatment was significantly stronger than Tetrac in suppressing $\mathrm{D} 2$ activity $(P<0.001)$. This difference in response, however, was not consistent over the dose levels considered. (Interaction between dose and treatment $<0.001$ for cortex, $P<0.01$ for BAT.) EU (WM), euthyroid; Hypo, hypothyroid. Values are means \pm S.E.M.

Table 3 The adjusted group means for each variable were estimated by analysis of covariance at the mean In (TSH) concentration. For SERCA $2 \mathrm{a}$ and cardiac monodeiodinase type 1 the slopes between $\mathrm{T}_{4}$ and Tetrac treatment were different and therefore the mean potency could not be estimated. The mRNA levels are expressed in arbitrary units (Phosphoimager).

\begin{tabular}{|c|c|c|c|c|c|c|c|}
\hline \multirow[b]{2}{*}{ Measurement } & \multirow[b]{2}{*}{ Organ } & \multirow[b]{2}{*}{$n$} & \multicolumn{2}{|c|}{ Adjusted means* } & \multirow[b]{2}{*}{$\mathrm{T}_{4} /$ Tetrac $\dagger$} & \multirow[b]{2}{*}{ Tetrac/T $4 \ddagger$} & \multirow[b]{2}{*}{$P$ value } \\
\hline & & & Tetrac-infused rats & $\mathrm{T}_{4}$-infused rats & & & \\
\hline Monodeiodinase type 1 activity & Liver & 62 & 106 & 180 & & $59 \%$ & $<0.001$ \\
\hline Monodeiodinase type $1 \mathrm{mRNA}$ & Liver & 27 & 2.48 & 5.1 & & $49 \%$ & $<0.03$ \\
\hline Monodeiodinase type 2 activity & Brain cortex & 61 & 27.7 & 5.02 & $18 \%$ & & $<0.001$ \\
\hline Monodeiodinase type 2 activity & BAT & 61 & 28 & 11.8 & $42 \%$ & & $<0.001$ \\
\hline$\beta$-MHC mRNA & Heart & 20 & 5.3 & 1.13 & $21 \%$ & & $<0.001$ \\
\hline$\alpha-\mathrm{MHC}$ mRNA & Heart & 24 & 328 & 495 & & $66 \%$ & $<0.19$ \\
\hline GH mRNA & Pituitary & 30 & 20280 & 28644 & & $71 \%$ & $<0.07$ \\
\hline Monodeiodinase type 2 mRNA & Pituitary & 20 & 2.00 & 1.25 & $60 \%$ & & $<0.001$ \\
\hline
\end{tabular}

* Each measurement in $\mathrm{T}_{4}$ - and Tetrac-treated rats.

† Activity of $\mathrm{T}_{4}$ in $\%$ of Tetrac.

$\ddagger$ Activity of Tetrac in $\%$ of $T_{4}$. 


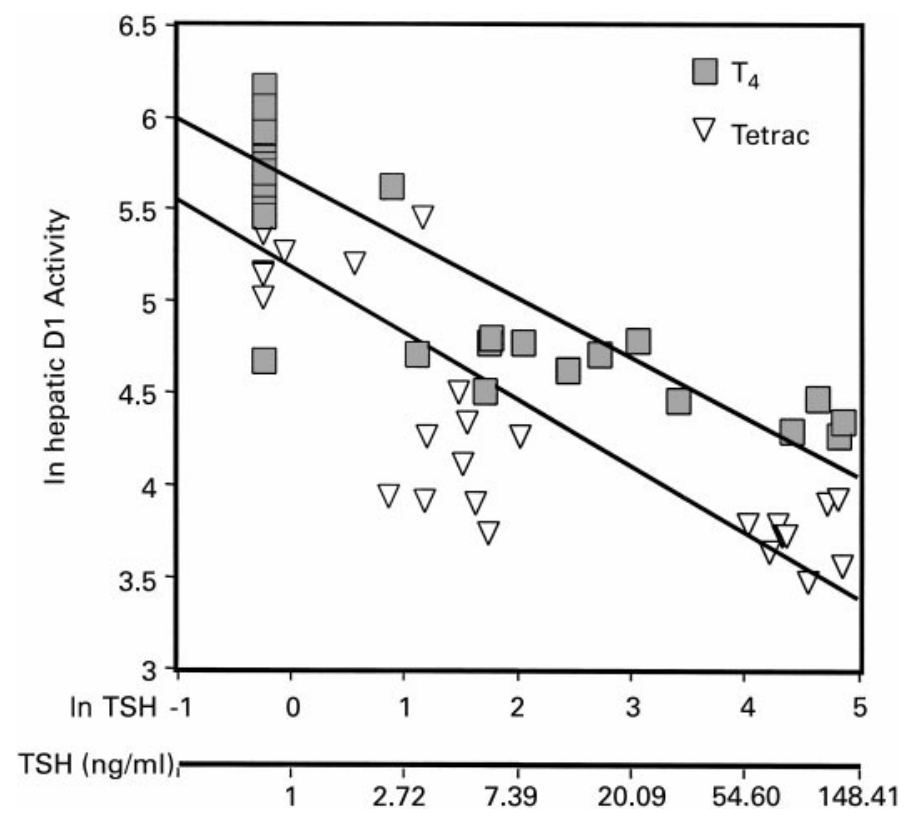

Figure $6 \mathrm{~A}$ reciprocal plot of the natural log of serum TSH vs the natural log of hepatic monodeiodinase type 1 (D1) activity. The slopes of the two curves are not significantly different allowing for the calculation of the adjusted group means of the hepatic monodeiodinase activity for $\mathrm{T}_{4}$-treated rats and Tetrac-treated rats at the overall mean In (TSH) of $1.43 \mathrm{ng} / \mathrm{ml}$. See Table 3 for results. some small differences between Triac and $\mathrm{T}_{3}$ would be found since Triac has a higher affinity for $\beta 1$ and $\beta 2$ receptors than $T_{3}$, yet only by a factor of approximately $2(19,25,26)$. There has been a recent report indicating that, based on in vitro transfection studies, Triac could selectively stimulate $\mathrm{T}_{3}$ receptor $\beta$ (TR- $\beta$ ) and be a preferential treatment for patients with thyroid hormone resistance (18). Our in vivo experiments indicate that the slopes of response of hepatic monodeiodinase type 1 and of serum TSH are not different, suggesting a similar mechanism of action. However, at the level of relative potencies, the in vivo data do not agree with what could be expected from in vitro data, since rat liver has mainly TR-1 receptors, an ideal substrate for Triac. Yet, according to Table 3, the potency of Triac on hepatic monodeiodinase type 1 is only about $50 \%$ of its effect on serum TSH levels. We have therefore to assume that in vivo the action of the hormones is the result of many factors, such as their metabolism, cellular and nuclear uptake and export. The relative importance of these factors may vary greatly and may differ from tissue to tissue.

Finally, none of the above-mentioned variables could explain the remarkable differences between the two hormones on the three heart parameters, monodeiodinase type $1, \beta-\mathrm{MHC}$ and, most importantly, SERCA $2 \mathrm{a}$ which confirm our studies with continuous Triac infusions. The fact that here the response to increasing doses of Tetrac is clearly less than for $\mathrm{T}_{4}$ indicates a fundamental difference in the mode of cardiac action for these two hormones. In this context, it is most interesting to note that a recently synthesized $\mathrm{T}_{3}$ analogue, GC- 1 , which has a high TR- $\beta$ specificity, shows similar discordant effects $(27-30)$.
Our results indicate two major findings for the action of Tetrac. On one hand, we have confirmed in vivo that Tetrac is a weak inhibitor of monodeiodinase type 2 activity and we show that for this reason, Tetrac is more potent than $\mathrm{T}_{4}$ in inhibiting serum TSH concentrations. Secondly, we have demonstrated that Tetrac is qualitatively different and less potent than $\mathrm{T}_{4}$ in stimulating cardiac hypertrophy and mRNA levels of SERCA 2a. The serum binding proteins of rats are different from humans; in the rat, tranthyretin is the major binding protein which binds with high-affinity Tetrac and Triac but also $\mathrm{T}_{4}$ and $\mathrm{T}_{3}$. One may therefore predict some differences between species. Nevertheless, it is possible that this substance may have the ideal profile for chronic treatment of patients with thyroid hormones, particularly if the treatment has, as an objective, complete serum TSH inhibition and its use should therefore be investigated in man.

\section{Acknowledgements}

The monodeiodinase type 2 activity measurements with a brain cortex microsomal protein fraction and addition of increasing Tetrac concentrations were kindly performed by Professor Theo Visser, Rotterdam. This work was supported by the Swiss National Research Foundation, Grant No 3100-53841.98, and by the Prévot Foundation, Geneva, Switzerland. We are grateful to Professor Hugo Studer, Berne, Switzerland and Professor E Danforth, Vermont, USA, for their valuable comments. 


\section{References}

1 Lerman J \& Pitt-Rivers R. Physiological activity of triiodo- and tetraiodothyroacetic acid in human myxoedema. Journal of Clinical Endocrinology and Metabolism 195616 1470-1479.

2 Lerman J, Harington CR \& Means JH. The physiologic activity of some analogues of thyroxine. Journal of Clinical Endocrinology and Metabolism $1956121306-1314$.

3 Lerman J. Dissociation of response to triiodothyroacetic acid in myxoedema: comparison with response to thyroid substance. Journal of Clinical Endocrinology and Metabolism 196121 10441053.

4 Burger AG, Engler D, Sakoloff C \& Staeheli V. The effects of tetraiodothyroacetic and triiodothyroacetic acids on thyroid function in euthyroid and hyperthyroid subjects. Acta Endocrinologica $197992455-467$.

5 Bracco D, Morin O, Schutz Y, Liang H, Jequier E \& Burger AG. Comparison of the metabolic and endocrine effects of 3,5,3'triiodothyroacetic acid and thyroxine. Journal of Clinical Endocrinology and Metabolism 199377 221-228.

6 Sherman SI \& Ladenson PW. Organ-specific effects of tiratricol: a thyroid hormone analog with hepatic, not pituitary, superagonist effects. Journal of Clinical Endocrinology and Metabolism $1992 \mathbf{7 5}$ 901-905.

7 Sherman SI, Ringel MD, Smith MJ, Kopelen HA, Zoghbi WA \& Ladenson PW. Augmented hepatic and skeletal thyromimetic effects of tiratricol in comparison with levothyroxine. Journal of Clinical Endocrinology and Metabolism 199782 2153-2158.

8 Juge-Aubry CE, Morin O, Pernin AT, Liang H, Philippe J \& Burger AG. Long-lasting effects of Triac and thyroxine on the control of thyrotropin and hepatic deiodinase type I. European Journal of Endocrinology 1995132 751-758.

9 Liang H, Juge-Aubry CE, O'Connell M \& Burger AG. Organspecific effects of 3,5,3'-triiodothyroacetic acid in rats. European Journal of Endocrinology 1997137 537-544.

10 Safran M, Farwell AP, Rokos H \& Leonard JL. Structural requirements of iodothyronines for the rapid inactivation and internalization of type II iodothyronine $5^{\prime}$-deiodinase in glial cells. Journal of Biological Chemistry 1993268 14224-14229.

11 Burger A, Reinharz A \& Ingbar SH. High-affinity binding of tetraiodothyroacetic acid by a prealbumin in normal rabbit serum. Endocrinology 197597 919-923.

12 Leonard JL \& Rosenberg IN. Characterization of essential enzyme sulfhydryl groups of thyroxine $5^{\prime}$-deiodinase from rat kidney. Endocrinology $1980 \mathbf{1 0 6} 444-451$.

13 Chomczynski P \& Sacchi N. Single-step method of RNA isolation by acid guanidinium thiocyanate-phenol-chloroform extraction. Analytical Biochemistry 1987162 156-159.

14 SAS/STAT User's Guide, edn. 4. Cary, NC: SAS Institute, 1989.

15 BMDP Statistical Software Manual, edn. 1. Eds WJ Dixon. Berkeley: University of California Press, 1992.

16 Burger AG \& Vallotton MB. The metabolism of tetraiodothyroacetic acid and its conversion to triiodothyroacetic acid. In Thyroid Hormone Metabolism, 223-239. London, New York, San Francisco: Academic Press, 1975.

17 Oppenheimer JH, Schwartz HL, Dillman W \& Surks MI. Effect of thyroid hormone analogues on the displacement of ${ }^{125}$ I-L-triiodothyronine from hepatic and heart nuclei in vivo: possible relationship to hormonal activity. Biochemical and Biophysical Research Communications 197355 544-550.

18 Takeda T, Suzuki S, Liu R-T \& DeGroot LJ. Triiodothyroacetic acid has unique potential for therapy of resistance to thyroid hormone. Journal of Clinical Endocrinology and Metabolism 1995 80 2033-2040.

19 Messier N \& Langlois MF. Triac regulation of transcription is T3 receptor isoform- and response element-specific. Molecular and Cellular Endocrinology 2000165 57-66.

20 Visser TJ, Leonard JL, Kaplan MM \& Larsen PR. Kinetics evidence suggesting two mechanisms for iodothyronine $5^{\prime}$-deiodination in rat cerebral cortex. PNAS $1982 \mathbf{7 9} 5080-5084$.

21 Kaplan MM, Visser TJ, Yaskoski KA \& Leonard JL. Characteristics of iodothyronine tyrosyl ring deiodination by rat cerebral cortical microsomes. Endocrinology $198311235-42$.

22 Goumaz MO, Kaiser CA \& Burger AG. Brain cortex reverse triiodothyronine $\left(\mathrm{r}_{\mathrm{T} 3}\right)$ and triiodothyronine concentrations under steady state infusions of thyroxine and $r_{\mathrm{T} 3}$. Endocrinology 1987 120 1590-1596.

23 Abend SL, Fang SL, Alex S, Braverman LE \& Leonard JL. Rapid alteration in circulating free thyroxine modulates pituitary type II $5^{\prime}$ deiodinase and basal thyrotropin secretion in the rat. Journal of Clinical Investigation $1991 \mathbf{8 8} 898-903$.

24 Silva JE \& Leonard JL. Regulation of rat cerebrocortical and adenohyphyseal type II 5'-deiodinase by thyroxine, triiodothyronine, and reverse triiodothyronine. Endocrinology $1985 \mathbf{1 1 6}$ 1627-1635.

25 Schueler PA, Schwartz HL, Strait KA, Mariash CN \& Oppenheimer JH. Binding of 3,5,3'triiodothyronine (T3) and its analogs to the in vitro translational products of c-erbA protooncogenes: differences in the affinity of the alpha- and betaforms for the acetic acid analog and failure of the human testis and kidney alpha-2 products to bind $\mathrm{T}_{3}$. Molecular Endocrinology $19904227-234$.

26 Schwartz HL, Strait KA, Ling NC \& Oppenheimer JH. Quantitation of rat tissue thyroid hormone binding receptor isoforms by immunoprecipitation of nuclear triiodothyronine binding capacity. Journal of Biological Chemistry $1992 \mathbf{2 6 7} 11794-$ 11799.

27 Chiellini G, Apriletti JW, al Yoshihara H, Baxter JD, Ribeiro RC \& Scanlan TS. A high-affinity subtype-selective agonist ligand for the thyroid hormone receptor. Chemistry and Biology 19985 299-306.

28 Ribeiro RC, Apriletti JW, Wagner RL, Feng W, Kushner PJ, Nilsson S et al. X-ray crystallographic and functional studies of thyroid hormone receptor. Journal of Steroid Biochemistry and Molecular Biology 199865 133-141.

29 Trost SU, Swanson E, Gloss B, Wang-Iverson DB, Zhang HJ, Volodarsky $\mathrm{T}$ et al. The thyroid hormone receptor-(-selective agonist GC-1 differentially affects plasma lipids and cardiac activity. Endocrinology 2000141 3057-3064.

30 Lazar MA. Editorial: A sweetheart deal for thyroid hormone Endocrinology $20001 \mathbf{1 4} 3055-3056$.

Received 6 July 2000

Accepted 19 October 2000 